\title{
Influence of board interlocking on earnings management*
}

Paulo Roberto da Cunha

Universidade Regional de Blumenau, Departamento de Contabilidade, Blumenau, SC, Brazil

\author{
Marcio Roberto Piccoli \\ Universidade do Oeste de Santa Catarina, Departamento de Ciências Contábeis, Joaçaba, SC, Brazil
}

Received on 05.12.2015 - Desk acceptance on 05.26.2015 - $6^{\text {th }}$ version approved on 12.10 .2016

\section{ABSTRACT}

The participation of directors on more than one board is called "board interlocking". This phenomenon contributes to the spread of management and governance practices, through directors sharing their knowledge and experiences on other boards. Thus, directors could "carry" the earnings management practices present in one company into another in which they sit on the board. It is assumed that the greater directors' direct or indirect connections on boards, the greater the sharing of information, especially information that can be reflected in company earnings quality. In light of the above, the aim of this study is to verify the influence of board interlocking on earnings management in companies listed on the São Paulo Stock, Commodities, and Futures Exchange (BM\&FBovespa). The study is characterized as descriptive, quantitative, and documentary, and uses a sample of companies listed on the BM\&FBOVESPA between 2011 and 2013. For earnings management, the model from Kang and Sivaramakrishnan (1995) was used; while for interlocking, degree centrality measures were used for direct board member connections, and intermediation centrality for indirect connections. The results indicate. that earnings management is influenced by the interlocking of board members. It is concluded that the greater the degree centrality, the greater positive earnings management is, and that variations in positive and negative accruals are influenced by board member intermediation. The results reinforce the idea that earnings management behavior can be transferred between companies by the directors that make up their boards.

Keywords: board interlocking, board of directors, earnings management, degree centrality, intermediation centrality.

\footnotetext{
*Paper presented at the IX Congress of the National Association of Post-Graduate

Programs in Accounting Sciences, Curitiba, PR, Brazil, June 2015.
} 


\section{INTRODUCTION}

In a corporate environment represented by managers and shareholders, stock market growth and the spread of capital ultimately favor manager autonomy, with managers taking decisions that are aligned with their own interests (Ribeiro \& Colauto, 2016; Santos \& Silveira, 2007) and that are sometimes not necessarily the same as those of shareholders. Agency theory discusses this conflict, with Fama and Jensen (1983) arguing that boards of directors are responsible for monitoring and mediating in this conflicting environment. In the view of Comet and Pizzaro (2011), along with this monitoring, boards are responsible for controlling the decisions taken by chairmen and chief executives, with the aim of defending shareholder interests. Conflicts of agency are common in the corporate environment from the moment the agent and principal in an organization have different objectives.

Boards of directors play an essential role in corporate governance, in which the legal prerogatives imposed on them range from hiring and firing to establishing manager compensation (Bruére, 2010; Williamson, 1985). Their role is to ensure equal treatment of shareholders and to intermediate between shareholder interests and manager practices, which thus makes boards important monitoring agents (Brenes, Madrigal \& Requena, 2011; Campbell, Ghosh, Petrova \& Sirmans, 2011).

The role of monitoring and reconciling manager actions with shareholder interests is strongly related with board independence. According to Fama and Jensen (1983) and Christensen, Kent, and Stewart (2010), board independence can be seen as a good corporate governance tool, contributing to greater monitoring of the practices adopted by managers. For Monks and Minow (1996), one of the main pillars of corporate governance is a strong board presence and composition in which there is member independence.

This context of board member composition can involve the participation of one member on more than one board. The literature calls this corporate practice "board interlocking"; that is, when a board member of one company sits on the board of another (Burt, 1979; Mizruchi, 1996). For Shropshire (2010), interlocking can be defined as director overlay, creating a network structure that can influence management decisions by sharing knowledge and experiences. For Hashim and Rahman (2011) and Shi, Dharwadkar, and Harris (2013), board interlocking can spread management and governance practices through the sharing of knowledge and experiences, which can be reflected in company earnings quality.

Company earnings quality reflects manager decisions and discretionary practices, which can involve management taking decisions opportunistically in order to maximize earnings without presenting the reality to other users. For Almeida (2010), earnings quality is relevant for understanding the incentives that influence executives and shareholders into interfering in the measurement of earnings and how these agents are influenced by such incentives, given that it is them who are responsible for the discretion involved in accounting choices. Martinez (2001) states that this practice is fundamentally characterized as an intentional alteration in accounting results, the aim of which is to achieve a particular motivation. It does not involve accounting fraud, as it is permitted under legislation and left to the judgment of each manager.

The presence of board interlocking can influence the adoption of discretionary practices that characterize earnings management. Earnings management is a process in which decisions are limited to the impositions of accounting rules in order to present a desired level of earnings (Schipper, 1989; Shi et al., 2013) that can benefit shareholders and managers.

Earnings management observed via board interlocking has a contagion effect on companies; that is, the participation of some members in other companies leads to good and bad management practices being shared between companies (Chiu, Teoh \& Tian, 2013).

Studies demonstrate a connection between earnings management practices and interconnections between board members (Carrera, 2013; Chiu et al., 2013; Mindzak, 2013; Shi et al., 2013). In the context of North American companies there are the studies from Carrera (2013) and Chiu et al., (2013). Mindzak (2013) conducted a study on Canadian companies and Shi et al. (2013) verified the relationship between interlocking boards of directors and audit committees in the North American setting. In Brazil, Ribeiro and Colauto (2016) related the interlocking of boards of directors with earnings management via income smoothing, however this relationship did not occur using the model from Kang and Sivaramakrishnan (1995) (KS Model) for verifying earnings management. Based on this context, in which the interconnection of board members can transfer the management practice experiences of the companies of which they sit on the board, and which can include earnings management, the following research problem is presented: what is the influence of board interlocking on earnings management in companies 
listed on the São Paulo Stock, Commodities, and Futures Exchange (BM\&FBOVESPA)? The aim of the study consists of verifying the influence of board interlocking on earnings management in companies listed on the BM\&FBOVESPA.

The study is warranted by the evolution of social networks and is relevant due to the importance of researching possible information transfers via board member interlocking, given the lack of empirical studies of this type in the area of accounting (Shi et al., 2013). For Chiu et al. (2013), by observing earnings management based on a social network, in this case board members, it can be identified why and when the context of this network is important for earnings quality, showing that the quality of information passed on influences the chances of earnings quality being affected.

Researching the interlocking of audit committees and boards of directors, Carrera (2013) affirms that studies such as these also provide insights based on Agency Theory; that is, the participation of a director on more than one board means that he/she does not have the time and resources necessary to effectively monitor an organization's objectives.

The study is also warranted for contributing to research in the area of corporate governance and social networks, since it seeks to investigate corporate interlocking and its relationship with earnings management, based on the exchange of information and knowledge of accounting practices originating from board member participation in more than one company. For Wong, Gigax, and Wang (2015), ignoring the essence of how relationship networks behave can result in unreliable statistics and incorrect conclusions being drawn.

The article is structured in the following way: section 2 presents the national and international literature review regarding board interlocking and earnings management, as well as the construction of the hypotheses of the study. Section 3 describes the methodology applied. Section 4 discusses the results from the statistical tests applied, and section 5 presents the conclusion.

\section{LITERATURE REVIEW}

\subsection{Board of Director Interlocking}

Ownership structure and conflicts of interest have always formed part of discussions on corporate governance. Corporate governance can be considered as an integrated set of internal and external controls aiming to harmonize shareholder and manager objectives (Baysinger \& Hoskisson, 1990) so that there are no conflicts of interest resulting from the separation between ownership and control (Berle \& Means, 1932; Jensen \& Meckling, 1976). The context of corporate governance practices includes the board of directors as a body that mediates in the conflict of interests between managers and shareholders. For Campbell et al. (2011), the board of directors is an important monitoring agent, particularly in corporate events in which managers' interests are tangential to shareholders' interests. The challenge for all board members is aligning business strategy with shareholder interests, in an environment in which shareholders aim to obtain value in the long run, while top management seeks growth and increased valuation in the short run (Brenes et al., 2011).

Considered an important mechanism of corporate governance, board performance in the eyes of managers is monitored based on their reputation in the market (Fama, 1980). Mace (1986) suggests that prestigious boards with possibilities for good business contacts can lead to the search for external members, resulting in members sitting on more than one board, influencing the size and independence of these boards.

Although there should be equilibrium in board size, in which there are internal and external members, the participation of internal members has been compromised by company interests, while external participation means meetings and decisions do not evolve (Salmon, 2001). On the other hand, Hsu and Petshsakulwong (2010) assert that external board members are more likely to dispute company interests due to them not having any economic relationship with management. Thus, the participation of independent board members produces improvements in earnings quality, thus reducing information asymmetry (Goh, Ng \& Young, 2012). It is observed that research on board of director independence has evolved and that this independence contributes to reducing agency problems, improving corporate governance practices (Carrera, 2013) and creating shareholder value (Hoitash, 2011).

It is noted that the authors, in addressing board independence, relate the external participation of directors and when they sit on more than one board and there is board interlocking; that is, when a member of a company board occupies a position on the board of another company. 
For decades, the practice of board interlocking has been quite a widely debated issue in corporate governance. In the United States of America, in 1914, Act n. 8 of Clayton, which aimed to prohibit competing companies from interlinking via corporate networks, did not achieve the desired success, since it lacked mechanisms for condemning this corporate practice. In 1992, the Securities and Exchange Commission (SEC) required all companies to report board interlocking in light of concerns about executive remuneration (Fich \& White, 2005).

In practice, board interlocking occurs in all sectors and has mostly been praised due to it mobilizing a scarce resource in organizations: manager and director experience (Fich \& White, 2005). For Nawfal (2011), large companies tend to present a greater number of interlocks, due to the experience, ability, and skills of their board members. Thus, Connelly, Johnson, Tihanyi, and Ellstrand (2011) affirm that being a member of a board of directors can benefit companies through external information communication channels.

Chiu et al. (2013) explain that most studies have sought to investigate the corporate behavior of organizations in different areas of earnings behavior based on board interlocking. In Brazil, the research addresses the issue in terms of company legitimacy and value (Rossoni \& Machado-da-Silva, 2013), political connections (Brey, Camilo, Marcon \& Alberton, 2011; Brey, Camilo, Marcon \& Bandeira-de-Mello, 2012; Camilo, Marcon \& Bandeirade-Melo, 2012; Costa, Bandeira-de-Melo \& Marcon, 2013; Macedo, Silva \& Machado, 2015), company reputation (Rossoni \& Guarrido, 2015), and earnings management (Ribeiro \& Colauto, 2016).

Rossoni and Machado-da-Silva (2013) evaluated how legitimacy conditions the market value of companies listed on the BM\&FBOVESPA. The board of an organization's position, resulting from board interlocking, was considered as being the origin of cultural-cognitive legitimacy. Rossoni and Machado-da-Silva (2013) argue that good board members tend to participate in a greater number of organizations, with the centrality and position of these members in a network revealing evidence of their prestige as executives, which thus means they are better positioned in the network and have a greater ability to access privileged information and resources.

Studies regarding interconnections between companies in the national setting are more comprehensive when they discuss them from the perspective of political connections. Brey et al. (2011) observed the relevance of political connections and ownership structure for the survival of organizations. Later, Brey et al. (2012) readdress the discussion of political connections by considering the interaction between Political Strategy Theory and Agency Theory, seeking to further examine the effects of political connections via ownership structure and the presence of the government as a shareholder.

Camilo et al. (2012) studied political connections and their effects on company performance using three proxies: donations to political campaigns, the hiring of members with political backgrounds to compose executive boards or boards of directors, and board interlocking activities. Costa et al. (2013) verified the influence of political connections in the diversification of Brazilian business groups.

Macedo et al. (2015) examined the issue from an analyst perspective and whether they would be likely to maintain their portfolios of investments in companies that have explicit political connections.

In an approach involving corporate reputation, Rossoni and Guarido (2015) analyzed how different markets (status), boards of directors, and organizational characteristics condition the reputation of publiclytraded Brazilian companies. The authors show that one of the ways of evaluating a board is via the structure of relationships between members, which is characterized as board interlocking, and in which good members are believed to participate in more organizations, which creates networks of relationships that can generate prestige.

Also in the national setting, the issue of board interlocking and earnings management was addressed by the study from Ribeiro and Colauto (2016), who related board interlocking with earnings management via income smoothing, unlike in this study, which verifies the influence of board interlocking on earnings management via variations in discretionary accruals using the KS Model. There have been other perspectives in the international arena, such as the studies from Carrera (2013), Chiu et al. (2013), Mindzak (2013), and Shi et al. (2013).

Chiu et al. (2013) found strong evidence that earnings management is transferred from company to company through the external relationships of board members, chief executive officers (CEOs), and audit committee members. They used panel data regression, identifying relationship networks based on degree centrality, intermediation, and proximity. Carrera (2013) related interlocking between audit committees and boards of directors with earnings management, using 13,065 observations of American companies between 2003 and 2010, and concluded that centralities measured via board member interlocking are positively associated with earnings management. 
Mindzak (2013) analyzed the formation of board interlocking and earnings management in Canadian companies. After analyzing 120 medium-sized companies, he was able to affirm that the interlinked companies presented less earnings management than the noninterlinked companies; that is, when interlinked, board members have a positive effect on earnings quality and long term company performance. Shi et al. (2013) sought to relate the interlocking of audit committees and boards of directors with earnings management. For the authors, the results are strongly inconsistent with the idea that similar companies simply select similar directors (even the same directors) and are strongly consistent with the theory of information transfer networks. The authors' findings support the hypothesis that companies do not need to belong to the same sector or field of activity for there to be board interlocking.

\subsection{Earnings Management}

It is observed that earnings management has become one of the main themes in the area of accounting and finance in the last decades (Santos \& Paulo, 2006). On the other hand, Trapp (2009) points out that there is extensive international literature on the subject, and that in Brazil it became the object of studies after Martinez (2001).

Earnings management, according to the definition from Schipper (1989, p. 92), is "intentional intervention in the external financial statement information process, with the aim of obtaining some private benefit (unlike in the neutral process of reporting financial results)". Schipper (1989) comments that this definition limits the discussion regarding earnings management when it includes only external communication of accounting statements and does not mention statements of a managerial nature.

Roychowdhury (2006) discusses management of operating activities, in which managers seek to develop actions that deviate from best accounting practices, with the aim of reporting better results in a different context and thus meeting their possible needs. For the author, decisions based on operating activities affect company cash flow and can also affect discretionary accruals. Along this same line of thinking, Kuo, Ning, and Song (2014) argue that management based on operating activities is related to governance mechanisms, in which strong and effective governance tends to increase investor protection and the quality of financial information, intensifying control in the capital market.

For Martinez (2001), it is important to understand that earnings management is not accounting fraud; that is, manager discretion is used when the rules give the option of applying this or that procedure and accounting choices are made that do not reflect business reality, but instead reflect incentives that lead to a different result being desired.

Despite not involving frauds or illicit acts, earnings management can negatively affect the primary function of accounting statements, which is to provide useful and reliable information for the user decision-making process (Fuji, 2004), in which income is one of the various signals used when taking decisions and making judgments.

In light of the above, the difference between cash basis accounting and accrual basis accounting lies in the timing of recognizing revenues and expenses. For Martinez (2001, p.16), accruals are defined as "the difference between net income and net cash flow"; that is, they would be "all of the income statement items included in income calculations, but which do not necessarily imply fund movements".

Since Healy (1985), the literature has addressed the methodology of verifying total accruals, which are divided into discretionary and non discretionary. For Goulart (2007, p. 43), "they are considered discretionary when they depend on the judgment of those preparing the financial statements". The choice of depreciation method is discretionary and it is in discretionary accruals that components of earnings management can be found, when in fact they should be used to provide truthful information on companies to the market (Trapp, 2009).

Discretionary accruals can be used as a measure of earnings management, in that the greater accruals are, the stronger or more evident earnings management is. Thus, positive (negative) accruals indicate an interest in increasing (decreasing) income or improving (reducing) results (Goulart, 2007). Martinez (2001) adds that discretionary accruals have the aim of managing accounting earnings.

In order to find total accruals (discretionary and non discretionary accruals), these can be calculated using information extracted from the Balance Sheet, from the Income Statement, and from the Cash Flow Statement (Goulart, 2007; Martinez, 2001; Paulo, 2007), in which various models can be used to measure variations in discretionary accruals, although no one model that can be considered as perfect. In this study the KS Model is used.

For Martinez (2001), perhaps because it involves a large number of variables and data, the KS Model is considered to be the most complete, both in an accounting sense, because it more efficiently describes the process of defining accruals, and in terms of statistical precision. However, for Martinez (2011), one of the biggest difficulties in adopting the model is in preparing data for multiple regression, due to its robustness and the quantity of accounting data that needs to be collected. 
Also for Martinez (2008, p.12), "out of all the current modern techniques the KS Model is the one that provides the best results" which is consistent with Thomas and Zhang (2001, p.364), who reviewed six earnings management models and also concluded that the KS Model is the most precise and the one that best adjusts to data treatment.

\subsection{Board Interlocking and Earnings Management}

Corporate governance presents mechanisms that contribute to the monitoring of managers, the board of directors being considered one of the main ones. This mechanism is responsible for implanting and monitoring strategic guidelines and relevant decisions in companies (Santos \& Silveira, 2007).

When companies are strategically aligned with others, they tend to share board members, and, in turn, can adopt similar organizational practices (Ribeiro \& Colauto, 2016). This phenomenon occurs, according to Chiu et al. (2013), as a result of observing behavior regarding the adoption of a particular action or the result generated by the chosen action. Companies can adopt similar organizational practices to others through the social ties that are created and by observing the actions and results adopted these other companies. In addition to this, the social ties created by companies through sharing board members can favor information exchanges between companies and the spread of different organizational practices.

These different organizational practices include earnings management, which can involve different types, such as: target earnings, income smoothing, big bath accounting (Martinez, 2008), observed via companies' discretionary accruals (the difference between net income and operating cash flow) (Mendes-Da-Silva, Onusic \& Bergmann, 2014), or via operating decisions that influence company cash flow (Martinez \& Cardoso, 2009).

It bears mentioning that corporate governance mechanisms and the sharing of board members can have an influence on companies adopting different organizational practices, one of which is earnings management. According to Ribeiro and Colauto (2016), the sharing of board members between companies favors the spread of earnings management both through operating decisions and through discretionary practices related to income. International and national authors have been concerned with this issue and have investigated the relationship between corporate governance mechanisms and board interlocking and different types of earnings management.

Dechow and Skinner (2000) argue that organizations with weak governance structures are more likely to develop earnings management practices. The study from Xie, Davidson, and Dadalt (2003) aimed to examine the role of boards of directors, of audit committees, and of executive boards in preventing earnings management. The findings enabled them to infer that boards of directors, audit committee members, and the activities carried out by audit committees are relevant factors that limit the readiness of board members to be involved in earnings management.

In the study from Chen, Elder, and Hsieh (2007), the aim was to investigate whether the characteristics of corporate governance are associated with earnings management in companies based in Taiwan. Among the results, they observed that board of director independence and expertise are associated with a lower probability of earnings management being carried out. Moreover, the study revealed that the enactment of the principles of good corporate governance practices resulted in a reduction in earnings management.

With regards to the studies that have evaluated the relationship between the sharing of board members (board interlocking) and earnings management, Chiu et al. (2013) evaluated whether earnings management (via discretionary accounts) spreads from company to company via board of director connections in companies in the United States of America. The results demonstrate that companies that share board members are more susceptible to manipulating earnings. They also verified that the spread of earnings management practices within companies with board interlocking is more intense when board members in leadership positions are shared, such as chairmen of the board.

In the national context, Ribeiro and Colauto (2016) analyzed the relationship between board interlocking and earnings management (income smoothing) in companies listed in the Bovespa Index. The findings revealed strong indications that board interlocking influences companies into manipulating their earnings via income smoothing. In general, they found that companies that share members with other organizations engage in different earnings management practices, which compromise the quality of the accounting information reported.

In light of this context, it is observed via empirical evidence from national and international studies that corporate governance and board interlocking have an influence on the adoption of different earnings management practices. With regards to board interlocking, this appears to be associated with the spread of earnings management between companies that share board members, and leads to the construction of the hypotheses. 


\subsection{Construction of the Hypotheses}

Connelly et al. (2011) highlight that interlocking aims to share knowledge and information and plays a crucial role in determining company strategies and overcoming investor uncertainty.

For Borgatti and Foster (2003), reducing uncertainty is also associated with strategic choices, in which board interlocking arises as an essential element, leading managers to observe the behavior of other companies and imitate and learn from their successes or failures. Thus, board member sharing and good accounting and governance practices are reflected in company performance and ultimately increase market value, thus benefitting shareholders (Yeo, Pochet \& Alcouffe, 2003).

Gulati and Westphal (1999) indicate that board interlocking offers a unique opportunity for linking up in order to exchange information, observe the leadership practices and style of pears, and witness the consequences of these practices first hand, and that the greater a board member's degree of centrality, the greater the probability of strategic cooperation between companies.

For Gulati and Westphal (1999), board interlocking is treated in a positive way, facilitating cohesion and the exchange of information between companies, and ignoring heterogeneity the more an information channel generates trust between board members. Therefore, it is understood that the greater the number of links between companies, the greater the exchange of information and experiences will be, which can even improve the accounting practices adopted. Wasserman and Faust (1994) state that the number of links between the actors in a network is measured by degree centrality. This is one of the main measures used in social studies. Freeman (1979) highlights that degree is simple and measured by the number of direct links involving a particular node or member in a network. Degree centrality is the simplest and most direct of the measures of centrality; that is, it reveals the number of links that an actor, in this case a board member, has with other board members in a network.

In light of the opinion that with board interlocking information is shared and that, according to Carrera
(2013), there is a positive relationship between degree centrality and earnings management, and that the greater the number of connections between board members, the greater the degree of management, we have the following hypotheses:

$\mathrm{H}_{1 \mathrm{a}}$ : the greater the degree centrality, the greater positive earnings management is;

$\mathrm{H}_{1 \mathrm{~b}}$ : the greater the degree centrality, the greater negative earnings management is.

Another measure of centrality normally used in network studies is intermediation centrality. Intermediation centrality aims to interlink actors who are not directly connected, demonstrating the importance of these intermediate actors in channeling information flows to other actors in a network (Freeman, 1979). Via intermediation centrality, small companies tend to interconnect themselves with large companies in order to reduce strategic uncertainties. Intermediation of interconnected boards channels information to central companies via the shortest path between the actors in a network (Elouaer-Mrizak \& Chastand, 2013).

The use of intermediation centrality can be considered as one of the most powerful measures of relationship intensity between companies (Elouaer-Mrizak \& Chastand, 2013). Companies interlinked via board interlocking are potential conductor wires for the sharing of information that can lead to earnings management behavior (Chiu et al., 2013). For Carrera (2013), variations in levels of earnings management are related to the degree of intermediation of the members in a network. As can be perceived, once board members simultaneously belong to other boards, they have the opportunity to communicate and exchange information. Via intermediation centrality, information and accounting practices are also indirectly shared, which leads us to also test the following hypotheses:

$\mathrm{H}_{2 \mathrm{a}}$ : the greater the intermediation centrality, the greater positive earnings management is;

$\mathrm{H}_{2 \mathrm{~b}}$ : the greater the intermediation centrality, the greater negative earnings management is. 


\section{RESEARCH METHODS AND PROCEDURES}

\subsection{Population and Sample}

The study is characterized as descriptive, quantitative, and documentary. The population is comprised of nonfinancial companies that compose the Brazilian capital market between 2011 and 2013, totaling 358 companies divided between nine different sectors, according to the BM\&FBOVESPA classification.

The sample was composed by studying the Reference Forms and item 12.6/8 of the 358 companies, available on the BM\&FBOVESPA website. First, the companies and active board members were tabulated. Then the companies with board members participating on other company boards were identified in order to compose the study sample for board interlocking.

It was found that 246 companies had one or more members on their boards who sat on the boards of other companies, thus resulting in board interlocking.

Of these 246 companies, it was verified that some did not present all of the information needed to apply the KS Model in order to calculate earnings management, resulting in a sample of 185 companies for 2011, 202 for 2012, and 201 for 2013. Table 1 shows the population and study sample.

Table 1 Population and study sample

\begin{tabular}{|c|c|c|c|c|c|}
\hline \multirow[t]{2}{*}{ Sector } & \multirow[t]{2}{*}{$\begin{array}{l}\text { Population } \\
\text { (n) }\end{array}$} & \multirow[t]{2}{*}{$\begin{array}{l}\text { Sample with } \\
\text { board interlocking } \\
\text { (n) }\end{array}$} & \multicolumn{3}{|c|}{$\begin{array}{l}\text { Sample with board interlocking and information } \\
\text { for calculating earnings management } \\
\text { (n) }\end{array}$} \\
\hline & & & 2011 & 2012 & 2013 \\
\hline Industrial goods & 35 & 21 & 17 & 19 & 19 \\
\hline Construction and transport & 70 & 53 & 35 & 39 & 39 \\
\hline Cyclical consumption & 68 & 43 & 34 & 34 & 34 \\
\hline Non-cyclical consumption & 45 & 29 & 20 & 22 & 21 \\
\hline Basic materials & 40 & 26 & 18 & 20 & 20 \\
\hline Oil, gas, and biofuels & 7 & 3 & 2 & 3 & 3 \\
\hline Information technology & 9 & 3 & 3 & 3 & 3 \\
\hline Telecommunications & 10 & 7 & 6 & 6 & 6 \\
\hline Public utility & 74 & 61 & 50 & 56 & 56 \\
\hline Total & 358 & 246 & 185 & 202 & 201 \\
\hline
\end{tabular}

Source: Developed by the authors. 
For Table 1 it is observed that board member participation in more than one company is considerable. Out of the 358 non-financial companies, 246 have one or more board members belonging to other company boards; that is, $68 \%$ of the non-financial companies listed on the BM\&FBOVESPA feature the formation of board interlocking.

It is perceived that the sector practicing interlocking the most is the public utilities sector, represented by almost $83 \%$, in which 62 companies were identified as having the characteristics of interconnected boards. On the other hand, the sector with the lowest proportion in the sample is information technology, with $33 \%$ of the companies.

\subsection{Study Variables}

In order to carry out the study, the panel data regression model was used, represented by the regression described in equation 1. Both the dependent and independent variables were obtained for each company $(i)$ and for each year analyzed $(t)$.

$$
\begin{aligned}
& A C D_{i t}=\beta_{0}+\beta_{1} D E G R E E_{-} C_{i t}+\beta_{2} B T W N \_C_{i t}+\beta_{3} I N D E P_{i t}+\beta_{4} S I Z E_{i t}+\beta_{5} D U A L C E O_{i t}+
\end{aligned}
$$

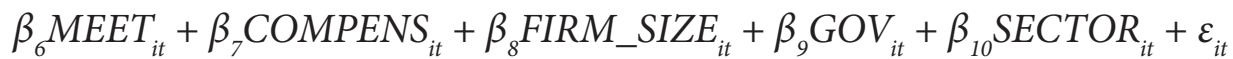

The dependent variable $A C D_{i t}$ (discretionary accruals of company $i$ in year $t$ ) is found via equation 2 (KS Model)

$$
A T_{i t}=\phi_{0}+\phi_{1}\left(\delta R_{i t}\right)+\phi_{2}\left(\delta_{2} E_{i t}\right)+\phi_{3}\left(\delta_{3} P P E_{i t}\right)+\varepsilon_{i t}
$$

in which $A T_{i t}=$ total accruals of company $i$ in period $t$, weighted by total assets at the end of period $t-1 ; R_{i t}=$ net revenues of company $i$ in period $t$, weighted by total assets at the end of period $t-1 ; E_{i t}=$ amount of costs and operating expenses of company $i$ in period $t$, excluding depreciation and amortization expenses, weighted by total assets at the end of period $t-1 ; P P E_{i t}=$ balance of fixed asset accounts (gross) of company $i$ at the end of period $t$, weighted by total assets at the end of period $t-1 ; \delta_{1, i t}=$ $C R_{i, t-1} / R_{i, t-1} ; \delta_{2, i t}=\left(I N V_{i, t-1}+\operatorname{PreExp} P_{i, t-1}+C P_{i, t-1}\right) / E_{i, t-1} ; \delta_{3, i t}=$ $D e p r_{i, t-1} / P P E_{i, t-1} ; C R_{i, t-1}=$ balance of (client) receivables of company $i$ in period $t$, weighted by total assets at the end of period $t-1 ; R_{i, t-1}=$ net revenue of company $i$ in period $t-1 ; I N V_{i, t-1}=$ balance of stock of company $i$ in period $t-1 ; \operatorname{PreEx}_{i, t-1}=$ balance of prepaid expenses of company $i$ in period $t-1 ;$ Depr $_{i, t-1}=$ amount of depreciation and amortization expenses of company $i$ in period $t-1 ; P P E_{i, t-1}$ $=$ balance of fixed assets and deferred assets (gross) of company $i$ at the end of period $t-1 ; \phi 0, \phi 1, \phi 2$ and $\phi 3=$ estimated coefficients from the regression; $\varepsilon_{i t}=$ regression error (residuals $=$ earnings management).

For better operationalization of the independent variables mentioned in equation 1 , a construct was elaborated (Table 2) with the respective variables used and operationalization of these. 
Table 2 Study construct

\begin{tabular}{|c|c|c|}
\hline \multirow{2}{*}{ Variables } & Operacionalization & Authors \\
\hline & \multicolumn{2}{|l|}{ Independent variables } \\
\hline DEGREE_C & $\begin{array}{l}\text { Number of direct links that a board member } \\
\text { has with the other board members in a network, } \\
\text { obtained using the UCINET®6 software. }\end{array}$ & $\begin{array}{l}\text { Carrera (2013), } \\
\text { Ribeiro and Colauto (2016). }\end{array}$ \\
\hline BTWN_C & $\begin{array}{l}\text { Number of indirect links that a board member } \\
\text { has with the other board members in a network, } \\
\text { obtained using the UCINET®6 software. }\end{array}$ & \\
\hline \multicolumn{3}{|c|}{ Independent control variables } \\
\hline INDEP & $\begin{array}{l}\text { Number of external members in relation to } \\
\text { total members on a board of directors. }\end{array}$ & $\begin{array}{l}\text { Bruére (2010), } \\
\text { Carrera (2013), } \\
\text { Chiu et al. (2013), } \\
\text { Santos and Silveira (2007), } \\
\text { Shi et al. (2013). }\end{array}$ \\
\hline DUALCEO & $\begin{array}{l}\text { Dummy variable: } 1 \text { when the positions of chief executive } \\
\text { officer (CEO) and chairman of the board are occupied by } \\
\text { different people and } 0 \text { if occupied by the same person. }\end{array}$ & $\begin{array}{l}\text { Carrera (2013), } \\
\text { Chiu et al. (2013), } \\
\text { Martinez (2001), } \\
\text { Shi et al. (2013). }\end{array}$ \\
\hline SIZE & Number of board members (size of the board). & $\begin{array}{l}\text { Carrera (2013), } \\
\text { Chiu et al. (2013), } \\
\text { Martinez (2001), } \\
\text { Silveira, Barros, and Fama (2003). }\end{array}$ \\
\hline COMPENS & Log of total board remuneration in relation to total members. & Mindzak (2013). \\
\hline MEET & Number of annual board meetings. & $\begin{array}{l}\text { Carrera (2013), } \\
\text { Mindzak (2013). }\end{array}$ \\
\hline FIRM_SIZE & Log of total assets. & $\begin{array}{l}\text { Carrera (2013), } \\
\text { Chiu et al. (2013), } \\
\text { Mindzak (2013), } \\
\text { Shi et al.(2013). }\end{array}$ \\
\hline GOV & $\begin{array}{l}\text { Level 1, Level 2, New Market, and Traditional, in which 1,2, 3, } \\
\text { and } 4 \text { are attributed to each level of governance, respectively. }\end{array}$ & $\begin{array}{l}\text { Carrera (2013), } \\
\text { Chiu et al. (2013), } \\
\text { Mindzak (2013), } \\
\text { Shi et al.(2013). }\end{array}$ \\
\hline SECTOR & $\begin{array}{l}\text { 1: oil, gas, and biofuels sector } \\
\text { 2: basic materials sector } \\
\text { 3: industrial goods sector } \\
\text { 4: construction and transport sector } \\
\text { 5: non-cyclical consumption sector } \\
\text { 6: cyclical consumption sector } \\
\text { 7: information technology sector } \\
\text { 8: telecommunications sector } \\
\text { 9: public utility sector }\end{array}$ & Martinez (2008). \\
\hline
\end{tabular}

BTWN_C: intermediation centrality; COMPENS: total board remuneration; DEGREE_C: degree centrality; DUALCEO: CEO duality; FIRM_SIZE: size; GOV: level of corporate governance; INDEP: board independence; MEET: number of annual board meetings; SECTOR: company economic sector; SIZE: board size.

Source: Developed by the authors. 


\subsection{Data Collection and Analysis}

The data for the variables in equations 1 and 2 were gathered from Reference Forms and by consulting the Economática database. Specifically in order to identify the boards of directors, the information contained in the Reference Forms available on the BM\&FBOVESPA website were used. In the Reference Form for each company, the effective members of the boards were identified for each year studied, in order to enable identification of the formation of company networks via board member interlocking. Subsequently, with the help of an electronic spreadsheet, quadratic form matrices were created to assist in identifying connections between companies. After creating the matrices, the UCINET 6 software was used to form the social networks and identify the degree of centrality and intermediation of the companies.

In order to compose the variables used in the KS Model (equation 2) of earnings management, all the variables were gathered from the Economática database, and for the control variables, the Reference Forms, Economática database, and BM\&FBOVESPA were analyzed. Table 3 specifies the items analyzed for each control variable.

Table 3 Collection of control variable data

\begin{tabular}{ll}
\hline Variables & Data collection source \\
\hline Board independence & Item 12.6/8 of the Reference Form \\
\hline Chief Executive Officer duality & Item 12.6/8 of the Reference Form \\
\hline Size of board & Item 13.2 of the Reference Form \\
\hline Total board remuneration & Item 13.2 of the Reference Form \\
\hline Number of annual board meetings & Item 13.4 of the Reference Form and company websites \\
\hline Size of assets & Economática ${ }^{\circledR}$ \\
\hline Level of corporate governance & BM\&FBOVESPA website \\
\hline Economic sector & BM\&FBOVESPA website \\
\hline
\end{tabular}

BM\&FBOVESPA = São Paulo Stock, Commodities, and Futures Exchange.

Source: Developed by the authors.

For the panel data regression analysis, two stages were carried out. The first involved applying multiple linear regression for the KS Model of earnings management metric in order to identify the level of company accruals in each year of the study, using the SPSS 21.0 software. In the second stage, after identifying board member interlocking

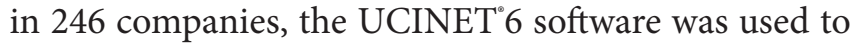
characterize the networks and identify the measures of centrality of degree and intermediation. After these two stages, the panel data regression was carried out, for which the Stata 13.0 software was used.

\section{DISCUSSION OF THE RESULTS}

This section presents the results regarding the influence of earnings management and measures of centrality based on the panel data regression statistical technique. The panel data regression analysis method is similar to that used by Carrera (2013), Mendes-Da-Silva, Rossoni, Martin and Martelanc (2008), and Ribeiro and Colauto (2016).

In order for it to be possible to carry out the two regressions and best identify the influence of interlocking and earnings management, the positive and negative accrual results were separated by year and by activity sector, resulting in 261 companies with positive accruals and 327 with negative accruals over the three years and totaling 588 observations in the analysis period, as observed in Table 4. 
Table 4 Discretionary accruals separated into positive and negative

\begin{tabular}{|c|c|c|c|c|c|c|}
\hline \multirow{2}{*}{ Sector } & \multicolumn{2}{|c|}{2011} & \multicolumn{2}{|c|}{2012} & \multicolumn{2}{|c|}{2013} \\
\hline & Positive & Negative & Positive & Negative & Positive & Negative \\
\hline Oil, gas, and biofuels & 1 & 1 & 1 & 2 & 2 & 1 \\
\hline Basic materials & 14 & 4 & 7 & 13 & 13 & 8 \\
\hline Industrial goods & 10 & 7 & 9 & 10 & 8 & 11 \\
\hline Construction and transport & 16 & 19 & 17 & 23 & 19 & 20 \\
\hline Non-cyclical consumption & 14 & 7 & 13 & 11 & 10 & 15 \\
\hline Cyclical consumption & 16 & 17 & 13 & 22 & 22 & 13 \\
\hline Information technology & 0 & 3 & 1 & 3 & 3 & 1 \\
\hline Telecommunications & 2 & 4 & 6 & 0 & 2 & 3 \\
\hline Public utility & 14 & 36 & 11 & 40 & 17 & 33 \\
\hline Total companies & 87 & 98 & 78 & 124 & 96 & 105 \\
\hline
\end{tabular}

Source: Developed by the authors.

By observing Table 4 it can be seen that in 2011 the construction and transport and cyclical consumption sectors present the greatest number of companies with positive accruals. In 2012, the non-cyclical consumption sector is included, and the companies also presented a tendency for positive earnings management. Analyzing 2013 , it can be observed that the result is the same as that found in 2011, in which the construction and transport and cyclical consumption sectors presented the greatest number of companies with positive earnings management, observed via discretionary accruals.

It is thus verified that the construction and transport and cyclical consumption sectors were the ones that maintained positive earnings management practices over the period analyzed.

When negative earnings management practices are observed, a similar result to positive earnings practices is found with regards to the sectors. In 2011, the public utility sector features with the greatest number of companies with negative earnings practices, followed by the construction and transport and consumption sectors. This picture is repeated in 2012. However, for 2013 the public utility and construction and transport sectors remain and the non-cyclical consumption sector is one of the sectors with the greater negative earnings management practices.

With the KS Model, it is generally noted that, independent of operating sector, the companies manage their earnings from one year to another; however, Table 4 shows that in the three years analyzed, the companies sought to report more losses and negatively managed their earnings.

Subsequent to this analysis, two panel data regressions were carried out, in which the first refers to positive accruals and the second to negative accruals, both relating board interlocking and the other control variables in order to test the hypotheses established in the study. The results of these regressions are shown in Table 5. 
Table 5 Earnings management: positive and negative accrual panel data

\begin{tabular}{|c|c|c|c|c|c|c|}
\hline \multirow[t]{2}{*}{ Variables } & \multicolumn{3}{|c|}{$\begin{array}{c}\text { Regression } 1 \\
\text { Positive accruals }\end{array}$} & \multicolumn{3}{|c|}{$\begin{array}{c}\text { Regression } 2 \\
\text { Negative accruals } \\
\end{array}$} \\
\hline & Coefficient & Standard error & t statistic & Coefficient & Standard error & t statistic \\
\hline DEGREE_C & $0.0365^{*}$ & 0.0117 & 3.11 & 1.0285 & 0.7170 & 1.43 \\
\hline BTWN_C & $0.2231^{* *}$ & 0.0670 & 3.33 & $0.3029^{* *}$ & 0.0351 & 8.61 \\
\hline FIRM_SIZE & -0.0178 & 0.0206 & -0.87 & $0.0590^{* *}$ & 0.0082 & 7.19 \\
\hline GOV & 0.0040 & 0.0028 & 1.45 & -0.0010 & 0.0867 & -0.01 \\
\hline SECTOR & 0.2488 & 0.1631 & 1.53 & -0.3325 & 0.6380 & -0.52 \\
\hline INDEP & $0.6139 * *$ & 0.1924 & 3.19 & 0.3190 & 0.4514 & 0.71 \\
\hline SIZE & $-0.0067 * *$ & 0.0170 & -0.39 & $0.0935^{*}$ & 0.0509 & 1.84 \\
\hline DUALCEO & -0.0800 & 0.0805 & -0.99 & 0.0079 & 0.2781 & 0.03 \\
\hline MEET & $-0.0157^{*}$ & 0.0076 & -2.07 & 0.0186 & 0.0171 & 1.09 \\
\hline COMPENS & -0.0267 & 0.0602 & -0.44 & 0.1172 & 0.2268 & 0.52 \\
\hline Constant & 0.1483 & 1.2889 & 0.12 & 2.0015 & 4.0680 & 0.49 \\
\hline $\mathrm{R}^{2}$ adjusted & & 39.19 & & & 61.03 & \\
\hline $\begin{array}{l}\text { F statistic } \\
\text { (probability) }\end{array}$ & & $\begin{array}{c}5.67 \\
(0.0000)\end{array}$ & & & $\begin{array}{c}20.68 \\
(0.0000)\end{array}$ & \\
\hline Observations & & 261 & & & 327 & \\
\hline
\end{tabular}

Note: The Breusch-Pagan and Hausman tests were carried out to better characterize the estimation model. The Breusch-Pagan test rejected hypothesis $\left(H_{0}\right)$ for both models, positive $($ sig. $=0.001)$ and negative $($ sig. $=0.001)$ accruals, concluding that the Random Effects Model is superior to the POLS model. The Hausman test concluded with the rejection of hypothesis $\left(H_{0}\right)$ and the superiority of the Fixed Effects Model compared with the Random Effects Model, for both models with positive and negative accruals (both with sig. $=0.000$ ). Thus, the best estimation model is Fixed Effects, presented in this table. To calculate the negative accruals model the sign was not disregarded; positive relationships must indicate that the greater the value of the variable, the lower the negative accrual score, and for negative relationships, the relationship is the opposite. For the models, the existence of endogeneity between the test variables [degree centrality (DEGREE_C), intermediation centrality (BTWN_C)] and accruals was verified. The models were estimated via $2 S L S$ and then the Durbin-Wu-Hausman test was applied, giving the following results: for positive accruals endogenous variable DEGREE_CP-value $(0.01)=1.00$ and BTWN_CP-value $(0.01)=1.00$; for negative accruals endogenous variable DEGREE_CP-value(4.30) $=0.8286$, BTWN_CP-value(4.20) $=0.8383$. Thus, in all of the cases, hypothesis $H_{0}$ for which there is no difference between the OLS and 2SLS estimations, cannot be rejected, and it is concluded that no endogenous effect exists. The best estimation is still OLS.

BTW_C = number of indirect links that a board member has with the other board members in a network, obtained using the UCINET ${ }^{\circledast} 6$ software; COMPENS = log of total board remuneration in relation to the total number of members; DEGREE_C $=$ number of direct links that a board member has with the other board members in a network, obtained using the UCINET ${ }^{\circledR} 6$ software; $^{\circ}$ DUALCEO = chief executive officer (CEO) duality (dummy variable in which in company $i$ the CEO is also the chairman of the board); FIRM_SIZE = size of assets (log of total assets); GOV = level of governance (Level 1, 2, New Market, and Traditional); INDEP = board independence (number of external members in relation to total board members); MEET = number of annual board meetings; SECTOR = economic sector (divided into nine sectors, as in the construct); SIZE = size of board (number of board members).

$*, * *$ : significant to $5 \%$ and $1 \%$, respectively.

Source: Developed by the authors.

In Table 5, it is statistically observed that accruals are not influenced by the variables degree centrality (positive accruals), intermediation centrality (negative accruals), size of assets (negative accruals), independence (positive accruals), size of board (positive and negative accruals), and number of board meetings (positive accruals). Along with these results, and in order to give more robustness to the findings (Wooldridge, 2010), the assumptions tests were verified for both the regression models. The results confirmed all of the normality of residuals assumptions, homoskedasticity, serial autocorrelation, and multicollinearity. It also bears mentioning that no variable is strongly correlated with the accruals measures, thus confirming that the parameter estimation model is robust and underpinning the results from the study.
As expected and similar to the result from Carrera (2013), it is noted from Table 5 that degree (DEGREE_C) and intermediation (BTWN_C) centralities exert an influence on earnings management practices, both for positive and for negative accruals. With regards to positive accruals, degree centrality (DEGREE_C) is statistically significant $(\hat{\beta}=0.0365 ; p<0.05)$, suggesting that the greater the degree centrality, the greater the positive earnings management, which means that the most central companies aim to positively manage their earnings via their board members. This suggests that positive earnings management practices in companies are directly perpetuated by other companies via their board members. For Carrera (2013), the greater the degree centrality (DEGREE_C), the greater the level of variation 
in accruals, and according to the results from the study, as degree centrality increases, companies are more likely to positively manage their earnings.

With regards to intermediation centrality, this is statistically significant $(\hat{\beta}=0.2231$ and $\hat{\beta}=0.3029 ; p<0.01$ ) in relation to positive and negative earnings management, indicating that indirect ties between companies, through board members, have an influence on company earnings quality. In this case, it is noted that positive and negative earnings management practices are indirectly perpetuated between companies via common board members in different companies. The results are similar to those in the study from Ribeiro and Colauto (2016), who also identified a statistically positive relationship between intermediation centrality of board members and income smoothing practices, and hence the probability of companies managing their earnings.

As a limitation in this study, it is important to highlight the possible presence of endogeneity in the relationship observed between board interlocking variables and earnings management, given that board characteristics, such as the presence of institutional investors, big banks, and government itself, may be influencing both earnings management practices and board connections. These board member characteristics were not investigated in this study, thus presenting an opportunity for further study.

Positive variations in accruals, as presented in Table 5 , are statistically influenced $(\hat{\beta}=0.6139$ and $\hat{\beta}=-0.0067 ; p<0.05)$ by the independence (INDEP) and size of boards, respectively. With regards to board independence, it is noted that the greater the independence, the greater the positive variations in accruals, as these are not statistically related with negative variations in accruals.

With regards to board size, the results shown indicate that, as size decreases, there are indications of positive earnings management, and that increases in the number of board members are statistically $(\hat{\beta}=0.0935 ; p<0.01)$ related with negative variations in earnings. Similar to Chiu et al. (2013) and Ribeiro and Colauto (2016), the results indicate that reductions or increases in the number of board members are statistically related with earnings management practices.

Also with regards to positive variations in accruals, it is verified via Table 5 that the number of board meetings (MEET) is statistically $(\hat{\beta}=-0.0157 ; p<0.01)$ related with positive earnings management practices. According to Elouaer-Mrizak and Chastand (2013), meetings are the time that board members have for face to face conversation. For Carrera (2013), the number of board meetings has a positive impact on earnings quality. Thus, while degree centrality exerts an influence on positive accruals and intermediation centrality is related to positive and negative variations, it is believed that, via board interlocking, accounting practices and valuable private information can be shared (Carrera, 2013).

With regards to negative variations in accruals, the size of assets variable is statistically $(\hat{\beta}=0.0590 ; p<0.01)$ related with negative variations in earnings. The results indicate similarity with the results from Carrera (2013), Chiu et al. (2013), and Ribeiro and Colauto (2016), which suggest that negative earnings management is related with company size, measured by assets.

The results from this study indicate that there is no statistically significant relationship between earnings management and board remuneration (COMPENS) and operating sector variables, which is similar to Carrera (2013), and also the case for CEO duality (Shi et al., 2013) and level of governance (GOV) (Erfhuth \& Bezerra, 2013). 


\section{CONCLUSION}

The aim of this study was to verify the influence of board interlocking on earnings management in companies listed on the BM\&FBOVESPA. Interlocking of board members was measured via degree centrality and intermediation centrality. A descriptive, documentary, and quantitative study was carried out, with a sample comprising 185 companies in 2011, 202 in 2012, and 201 in 2013, which varied depending on data availability. The results indicate that earnings management can be influenced by board member interlocking.

Earnings management, measured using the KS Model (1995), indicated positive or negative earnings management behavior. It was found that the greater the social network directly established between board members, the greater the positive earnings management, which supports the findings of Carrera (2013).

Positive and also negative earnings management behavior can be observed via intermediation centrality; that is, when such management behavior is indirectly spread between companies via the same members sitting on different company boards. These results are similar to those from Ribeiro and Colauto (2016), who identified a positive connection between intermediation centrality and income smoothing in New Market companies. The results indicate that, despite intermediation centrality influencing positive and negative earnings management, the greatest variation occurs in relation to negative earnings management.

Besides finding influences of board interlocking on earnings management, it was verified that accruals are also influenced by size of assets (negative accruals), independence (positive accruals), size of board (positive and negative accruals), and number of board meetings (positive accruals).

It is thus highlighted that the greater a board's independence, the greater the positive variation in accruals, which is in line with the findings of Bruére (2010), Carrera (2013), and Mizruchi (1996). When board size is observed, the results indicate that when there is a reduction in size, there are indications of positive earnings management. On the other hand, when board size increases, there is a negative variation in earnings. These results for the size of board variable are similar to those from Chiu et al. (2013). The number of meetings is also related with earnings management, since it was identified that a reduction in the number of meetings increases positive accruals, which is consistent with Carrera (2013).
In terms of a new contribution from the article to the area of study, convergence with the results of international studies stands out, especially by using the KS Model of earnings management, which had not yet been verified in the Brazilian context. Other studies find this relationship between board interlocking and earnings management via other management metrics, such as the modified Jones model (Carrera, 2013) and income smoothing (Ribeiro \& Colauto, 2016). This result reinforces the idea that earnings management behavior can be perpetuated via board members who sit on the boards of different companies.

It bears mentioning that this perpetuation of behavior via boards of directors can reinforce earnings management practices involving capital market related motivations, contractual motivations between companies and stakeholders, government regulations (Healy \& Wahlen, 1999), and political costs (Martinez, 2001). This can have regulatory implications that inhibit the effect of this sharing of information due to the centrality that a board member exerts in a network of relationships, with some regulations restricting the number of boards on which a board member can sit at the same time. The Brazilian Institute for Corporate Governance (2010) advises that these participations on different boards should be analyzed from the perspective of avoiding conflicts of interest and verifying whether board members have enough time to adequately carry out their activities.

One limitation of the study involves the possible existence of endogeneity between the board interlocking and earnings management variables, as the presence of institutional investors, big banks, and government itself on boards could influence both motivations for practicing EM and the configuration of board connections itself, thus presenting an opportunity for further research.

Also for future research, we suggest applying other earnings management models identified in the literature, which could be applied in different countries, such as the modified Jones model (Dechow, Sloan, \& Sweeney, 1995), which is quite widely used in the international literature. We also recommend that based on the construct of this study it is also possible to use other statistical measures to measure the relationship between board interlocking and earnings management. Clusters and rankings are some of the measures that could possibly be used. 


\section{REFERENCES}

Almeida, J. E. F. (2010). Qualidade da informação contábil em ambientes competitivos (Doctoral Thesis), Ciências Contábeis, Universidade de São Paulo, São Paulo.

Baysinger, B., \& Hoskisson, R. E. (1990). The composition of boards of directors and strategic control: effects on corporate strategy. Academy of Management Review, 15(1), 72-87.

Berle, A., Jr. \& Means, G. (1932). The modern corporation and private property. Chicago (IL): Commerce Clearing House.

Borgatti, S. P., \& Foster, P. C. (2003). The network paradigm in . organizational research: a review and typology. Journal of Management, 29(6), 991-1013.

Brenes, E. R., Madrigal, K., \& Requena, B. (2011). Corporate governance and family business performance. Journal of Business Research, 64(3), 280-285.

Brey, N. K., Camilo, S. P. O., Marcon, R:, \& Alberton, A. (2011). A estrutura de propriedade das corporações: conexões políticas sob a perspectiva da dependência de recursos - um ensaio teórico. Revista Ibero-Americana de Estratégia, 10(3), 126-146.

Brey, N. K., Camilo, S. P. O., Marcon, R., \& Bandeira-de-Mello, R. (2012). Conexões políticas das empresas por estruturas de propriedade: uma abordagem do governo como acionista. RACE: Revista de Administração, Contabilidade e Economia, 11(2), 319-350.

Bruére, A. J. (2010). Influência do board interlocking no valor e desempenho financeiro das empresas listadas na BMFBovespa (Master's Degree). Administração, Faculdade Boa Viagem, Recife.

Burt, R. S. (1979). A structural theory of interlocking corporate directorates. Social Networks, 1(4) 415-435.

Camilo, S. P. O., Marcon, R., \& Bandeira-de-Mello, R. (2012). Conexões políticas das firmas e seus efeitos na performance: uma convergência entre as perspectivas da governança e da dependência de recursos - um ensaio teórico. Revista Alcance, 19(2), 241-258.

Campbell, R. D., Ghosh, C., Petrova, M., \& Sirmans, C. F. (2011). Corporate governance and performance in the market for corporate control: the case of REIT's. The Journal of Real State Finance and Economics, 42(4), 451-480.

Carrera, N. (2013). Audit committees' interlocks and financial reporting Quality. In $36^{\circ}$ Annual Congress European Accounting Association, Paris, France.

Chen, K. Y., Elder, R. J., \& Hsieh, Y. M. (2007). Corporate governance and earnings management: the implications of corporate governance best-practice principles for Taiwanese listed companies. Journal of Contemporary Accounting Economics, 3(2), 73-105.

Chiu, P. C., Teoh, S. H., \& Tian, F. (2013). Board interlocks and earnings management contagion. The Accounting Review, $88(3), 915-944$.

Christensen, J., Kent, P., \& Stewart, J. (2010). Corporate governance and company performance in Australia. Australian Accounting Review, 20(4), 372-386.

Comet, C., \& Pizarro, N. (2011). The cohesion of intercorporate networks in France. Procedia-Social and Behavioral Sciences, 10, 52-61.
Connelly, B. L., Johnson, J. L., Tihanyi, L. \& Ellstrand, A. E. (2011). More than adopters: competing influences in the interlocking directorate. Organization Science, 22(3), 688-703.

Costa, M., Bandeira-de-Mello, R., \& Marcon, R. (2013). Influência da conexão política na diversificação dos grupos empresariais brasileiros. Revista de Administração de Empresas, 53(4), 376387.

Dechow, P. M., \& Skinner, D. J. (2000). Earnings management: reconciling the views of accounting academics, practitioners, and regulators. Accounting Horizons, 14(2), 235-250.

Dechow, P. M., Sloan, R. G., \& Sweeney, A. P. (1995). Detecting earnings management. The Accounting Review, 70(2), 193-225.

Elouaer-Mrizak, S., \& Chastand, M. (2013). Detecting communities within French intercorporate network. ProcediaSocial and Behavioral Sciences, 79, 82-100.

Erfhuth, A. E., \& Bezerra, F. A. (2013). Gerenciamento de resultados nos diferentes níveis de governança corporativa. Revista Base (Administração e Contabilidade) da UNISINOS, 10(1), 32-42.

Fama, E. F. (1980). Agency problems and the theory of the firm. The Journal of Political Economy, 88(2), 288-307.

Fama, E. F., \& Jensen, M. C. (1983). Separation of ownership and control. Journal of Law and Economics, 26(jun), 301-325.

Fich, E. M., \& White, L. J. (2005). Why do CEOs reciprocally sit on each other's boards? Journal of Corporate Finance, 11(1), 175-195.

Freeman, L. C. (1979). Centrality in social networks conceptual clarification. Social Networks, 1(3), 215-239.

Fuji, A. H. (2004). Gerenciamento de resultados contábeis no âmbito das instituições financeiras atuantes no Brasil (Master's Degree). Ciências Contábeis, Universidade de São Paulo, São Paulo.

Goh, B. W., Ng, J., \& Yong, K. O. (2012). The effect of board independence on the information environment: an instrumental variable approach based on director social network. In Annual Meeting American Accounting Association, Washington, D.C.

Goulart, A. M. C. (2007). Gerenciamento de resultados contábeis em instituições financeiras no Brasil (Doctoral Thesis). Ciências Contábeis; Universidade de São Páulo, São Paulo.

Gulati, R., \& Westphal, J. D. (1999). Cooperative or controlling? The effects of CEO-board relations and the content of interlocks on the formation of joint ventures. Administrative Science Quarterly, 44(3), 473-506.

Hashim, H. A., \& Rahman, M. S. A. (2011). Multiple board appointments: are directors effective? International Journal of Business and Social Science, 2(17), 137-143.

Healy, P. M., \& Wahlen, J. M. (1999). A review of the earnings management literature and its implications for standard setting. Accounting Horizons, 13(4), 365-383.

Healy, P. M. (1985). The effect of bonus schemes on accounting decisions. Journal of Accounting and Economics, 7(1), 85-107.

Hoitash, U. (2011). Should independent board members with social ties to management disqualify themselves from serving on the board? Journal of Business Ethics, 99(3), 399-423. 
Hsu, W. Y., \& Petchsakulwong, P. (2010). The impact of corporate governance on the efficiency performance of the Thai non-life insurance industry. The Geneva Papers on Risk and InsuranceIssues and Practice, 35(1), 28-49.

Instituto Brasileiro de Governança Corporativa. (2010). Código das melhores práticas de governança corporativa (4a. ed.). São Paulo, SP: IBGC.

Jensen, M. C., \& Meckling, W. H. (1976). Theory of the firm: managerial behavior, agency costs, and ownership structure. Journal of Financial Economics, 3(4), 305-360.

Kang, S. H., \& Sivaramakrishnan, K. (1995). Issues in testing earnings management and an instrumental variable approach. Journal of Accounting Research 33(2), 353-367.

Kuo, J. M., Ning, L., \& Song, X. (2014). The real and accrualsbased earning management behaviors: evidence from the split share structure reform in China. The International Journal of Accounting, 49(1), 101-136.

Mace, M. 1986. Directors: $m y t h$ and reality. Boston, MA: Harvard Business School Press.

Macedo, J. M. A., Silva, C. A. T., \& Machado, M. A. V. (2015). Conexões políticas e as empresas brasileiras: um estudo experimental sobre as decisões de investimento no mercado de capitais. Advances in Scientific and Applied Accounting, 8(2), 157-178.

Martinez, A. L., \& Cardoso, R. L. (2009). Gerenciamento da informação contábil no Brasil mediante decisões operacionais. Revista Eletrônica de Administração, 15(3), 600-626.

Martinez, A. L. (2001). Gerenciamento dos resultados contábeis: estudo empírico das companhias abertas brasileiras (Doctoral Thesis). Ciências Contábeis, Universidade de São Paulo, São Paulo.

Martinez, A. L. (2008). Detectando earnings management no Brasil: estimando os accruals discricionários. Revista Contabilidade \& Finanças, 19(46), 7-17.

Mendes-Da-Silva, W., Onusic, L. M., \& Bergmann, D. R. (2014). The influence of e-disclosure on the ex-ante cost of capital of listed companies in Brazil. Journal of Emerging Market Finance, 13(3), 335-365.

Mendes-Da-Silva, W., Rossoni, L., Martin, D. M. L., \& Martelanc, R. (2008). A influência das redes de relações corporativas no desempenho das empresas do Novo Mercado da BOVESPÁ. Revista Brasileira de Finanças, 6(3), 337-358.

Mindzak, J. (2013). Interlocked boards of directors, voluntary disclosures and earnings quality. Voluntary disclosures and earnings quality. In CAAA Annual Conference, School of Business Economics. Montreal, Canadá.

Mizruchi, M. S. (1996). Cohesion, structural equivalence, and similarity of behavior: an approach to the study of corporate political power. Sociological Theory, 22, 271-298.

Monks, R. A., \& Minow, N. (1996). Watching the watchers: corporate governance for the 21st century. Cambridge, MA: Blackwell.

Nawfal, W. (2011). Interlocking directors: impact on canadian merger and acquisition outcomes (Doctoral Thesis). Administração, John Molson School of Business, Concordia University, Montreal, Canadá.
Paulo, E. (2007). Manipulação das informações contábeis: uma análise teórica e empírica sobre os modelos operacionais de detecção de gerenciamento de resultados (Doctoral Thesis). Ciências Contábeis, Universidade de São Paulo, São Paulo.

Ribeiro, F., \& Colauto, R. D. (2016). A relação entre board interlocking e as práticas de suavização de resultados. Revista Contabilidade \& Finanças, 27(70), 55-66.

Rossoni, L., \& Guarido Filho, E. R. (2015). O que faz um nome? Status, conselho de administração e características organizacionais como antecedentes da reputação corporativa. Revista de Administração RAUSP, 50(3), 292-309.

Rossoni, L., \& Machado-da-Silva, C. L. (2013). Legitimidade, governança corporativa e desempenho: análise das empresas da BMFBovespa. Revista de Administração de Empresas; 53(3), 272-289.

Roychowdhury, S. (2006). Earnings management through real activities manipulation. Journal of Accounting and Economics, 42(3), 335-370.

Salmon, W. J. (2001). Prevenção de crises: como engrenar o conselho. In Harvard business review: experiências de governança corporativa (pp. 9-31). Rio de Janeiro, RJ: Campus.

Santos, A., \& Paulo, E. (2006). Diferimento das perdas cambiais como instrumento de gerenciamento de resultados. $B B R$ Brazilian Business Review, 3(1), 15-31.

Santos, R. L., \& Silveira, A. D. M. D. (2007). Board interlocking no Brasil: a participação de conselheiros em múltiplas companhias e seu efeito sobre o valor das empresas. Revista Brasileira de Finanças, 5(2), 125-163.

Schipper, K. (1989). Commentary on earnings management. Accounting horizons, 3(4), 91-102.

Shi, L., Dharwadkar, R., \& Harris, D. (2013). Board interlocks and earnings quality [Working Paper]. Social Science. Research Network. Retrieved from http://wwwl,american. edu/academic.depts/ksb/finance_realestate/mrobe/Seminar/ dharwakar.pdf.

Shropshire, C. (2010). The role of the interlocking director and board receptivity in the diffusion of practices. Academy of Management Review, 35(2), 246-264.

Silveira, A. D. M. D., Barros, L. A. B. D. C., \& Fama, R. (2003). Estrutura de governança e valor das companhias abertas brasileiras. Revista de Administração de Empresas, 43(3), 5064.

Thomas, J., \& Zhang, X. (2001). Identifying unexpected accruals: a comparison of current approaches. Journal of Accounting and Public Policy, 19(4), 347-376.

Trapp, A. C. G. (2009). A relação do conselho fiscal como componente do controle no gerenciamento de resultados contábeis (Doctoral Thesis) Ciências Contábeis, Universidade de São Paulo, São Paulo.

Wasserman, S., \& Faust, K. (1994). Social network analysis: methods and applications. Cambridge, MA: Cambridge University Press.

Williamson, O. E. (1985). The economic institutions of capitalism: firms. markets, relational contracting. New York (NY): Free Press. 
Wong, L. H., Gygax, A., \& Wang, P. (2015). Board interlocking network and the design of executive compensation packages. Social Networks, 41, 85-100. Retrieved from http://dx,doi. org/10.1016/j.socnet.2014.12.002.

Wooldridge, J. M. (2010). Econometric analysis of cross section and panel data (2a. ed.). Cambridge, MA: The MIT Press.
Xie, B., Davidson, W. N., \& Dadalt, P. J. (2003). Earnings management and corporate governance: the role of the board and the audit committee. Journal of Corporate Finance, 9(3), 295-316.

Yeo, H. J., Pochet, C., \& Alcouffe, A. (2003). CEO reciprocal interlocks in French corporations. Journal of Management and Governance, 7(1), 87-108.

Correspondence address:

Paulo Roberto da Cunha

Universidade Regional de Blumenau

Rua Antônio da Veiga, 140, Campus 1, Sala D-101 - CEP: 89012-500

Victor Konder - Blumenau - SC - Brasil

Email: pauloccsa@furb.br 